\title{
Perbedaan Daya Hambat Bakteri dari Propolis Cair yang Ada di Pasaran Terhadap Escherichia Coli dan Staphylococcus Aureus Secara In Vitro
}

\author{
Bangun Azhari Yusuf ${ }^{1}$, Aziz Djamal², ${ }^{2}$ sterina $^{3}$
}

\begin{abstract}
Abstrak
Propolis adalah zat yang digunakan lebah melindungi sarangnya dari berbagai ancaman. Komponen utama propolis adalah resin yang dikumpulkan lebah dan dicampur dengan air liurnya. Manusia juga menggunakan propolis sebagai obat berbagai penyakit, seperti infeksi bakteri. Propolis memiliki kemampuan antibakteri terhadap Escherichia coli dan Staphylococcus aureus. Kualitas dan jenis propolis sesuai dengan komposisi kimia, iklim dan tempat berkembang biak. Tujuan penelitian ini adalah melihat perbedaan daya hambat bakteri Propolis cair 1 dan Propolis cair 2 yang ada di pasaran terhadap Escherichia coli dan Staphylococcus aureus secara in vitro. Propolis yang akan diuji adalah propolis cair yang ada di pasaran dipilih dua secara acak. Penelitian dilaksanakan pada bulan Januari 2013 di laboratorium Mikrobiologi Fakultas Kedokteran Universitas Andalas. Jenis penelitian eksperimental menggunakan metode difusi (metode cakram) dan analitik dengan menghubungkan perbedaan kedua propolis sebagai antibakteri. Hasil penelitian ini menunjukkan propolis cair 1 dan propolis cair 2 yang ada di pasaran tidak memiliki efek antibakteri terhadap Escherichia coli dan terdapat perbedaan daya hambat bakteri dari kedua propolis terhadap Staphylococcus aureus. Propolis cair 2 (diklaim berasal dari Selandia baru) memiliki daya hambat bakteri yang lebih baik daripada propolis cair 1 (diklaim berasal dari Malaysia).
\end{abstract}

Kata kunci: propolis cair, perbedaan daya hambat bakteri, Escherichia coli, Staphylococcus aureus

\section{Abstract}

Propolis is substance which use to protect bee hive from various threat. The main component of propolis is resin which is collected and mixed with saliva. The human also use propolis as a treatment against various illness such as bacterial infection. Propolis has an antibacterial effect to Escherichia coli and Stahpylococcus aureus. The quality and type of propolis is also in accordance with chemical composition, climate and their breeding location. The objective of this study was to find out the differentiation of the antibacterial effect of Propolis 1 and Propolis 2 in the market to Escherichia coli and Staphylococcus aureus by in vitro. Propolis to be tested for this study is random liquid propolis in the market. Research was conducted in January 2013 in the laboratory of Microbiology Faculty of Medicine, University of Andalas. This type of study was the experimental diffusion method (disc method) and the analytic distinction owned by linking two of propolis as an antibacterial effect. These results indicate that propolis 1 and propolis 2 have no ability antibacterial effect to Escherichia coli, and both of propolis have differences antibacterial effect to Staphylococcus aureus. Propolis 2 (from New Zealand claimed) has antibacterial effect better than propolis 1 (from Malaysia claimed).

Keywords: propolis, differentiation of the antibacterial effect, Escherichia coli, Staphylococcus aureus

Affiliasi penulis: 1. Pendidikan Dokter FK UNAND (Fakultas Kedokteran Universitas Andalas, Padang), 2. Bagian Mikrobiologi FK UNAND, 3. Bagian Kimia FK UNAND

Korespondensi: Bangun Azhari Yusuf, E-mail :

bangunazhariyusuf@gmail.com, Telp: 085211470927

\section{PENDAHULUAN}

Propolis (lem lebah) adalah zat yang di ekstrak dari resin yang dikumpulkan oleh lebah pekerja khusus yang tugasnya mencari resin dari daun yang baru tumbuh dan bagian kulit batang pohon tertentu. 
Fungsi propolis yang paling penting bagi lebah adalah membungkus (memumikan) bangkai binatang yang masuk ke sarang lebah agar tidak menyebarkan penyakit. Belajar dari efektifitas propolis bagi lebah inilah manusia modern ikut menggunakan propolis dalam pengobatan khususnya untuk menghentikan pertumbuhan dan penyebaran bakteri, virus dan jamur. Dalam dunia pengobatan, lem lebah (propolis) berkhasiat menurunkan tekanan darah tinggi, memperlancar air seni, antibakteri, membunuh virus influenza, antivirus dan antitumor. Beberapa komponen propolis seperti flavonoid dan etanol berfungsi sebagai antioksidan serupa dengan vitamin E. Melihat potensi propolis ini, maka perlu dibuktikan secara ilmiah tentang potensi dan pemanfaatan propolis terutama sebagai antibakteri. ${ }^{1}$

Berdasarkan riset di luar maupun dalam negeri, propolis terbukti ampuh melawan beberapa penyakit berat. Penelitian telah banyak dilakukan baik secara invivo maupun invitro dan hasilnya menunjukkan bahwa propolis memiliki beberapa aktivitas biologis dan farmakologis antara lain bersifat antibakteri baik terhadap gram positif maupun gram negatif. Dilaporkan propolis hasil ekstrak etanol $70 \%$ dapat digunakan sebagai senyawa antibakteri, baik bakteri gram positif (Staphilococcus aureus dan Bacillus subtilis), maupun bakteri gram negatif (Escherichia coli). Konsentrasi hambat tumbuh minimum dari ekstrak propolis masing-masing untuk setiap bakteri adalah 0,39\% terhadap Staphilococcus aureus, 0,78\% terhadap Bacillus subtilis dan $0,78 \%$ terhadap E. coli. Di dalam negeri, penelitian yang dilakukan pada tahun 2005 tentang aktivitas antibakteri flavonoid propolis Trigona sp terhadap bakteri Streptococus mutans penyebab karies gigi menunjukkan adanya kemampuan hambatan terhadap pertumbuhan Streptococcus mutans. ${ }^{1-3}$

Resistensi antibiotik yang makin lama makin luas karena adanya pemakaian tidak taat aturan dari masyarakat menjadi salah satu faktor yang mendorong WHO untuk menyarankan pemakaian bahan alam untuk pengobatan yang dikenal juga dengan istilah back to nature. ${ }^{3}$

Staphilococcus aureus merupakan salah satu genus dari Staphylococcus yang bersifat patogen utama bagi manusia. Bakteri ini merupakan bentuk koagulase positif, hal ini membedakannya dari spesies Staphylococcus lainnya karena koagulase negatif (S.epidermidis, S.warneri, S.hominis dan spesies lainnya) merupakan flora normal manusia dan jarang menyebabkan infeksi. Infeksi $S$. aureus dapat disebabkan kontaminasi langsung pada luka. Misalnya pada infeksi luka pascabedah oleh Staphylococcus atau infeksi setelah trauma. ${ }^{4-6}$

Escherichia coli adalah salah satu bakteri enterik dan anggota flora usus normal. Bakteri ini pada umumnya tidak menyebabkan penyakit dan di dalam usus berperan terhadap fungsi dan nutrisi normal. Bakteri menjadi bersifat patogen apabila berada di luar usus, yaitu lokasi normal tempatnya berada atau di lokasi lain dimana flora normal jarang terdapat. Ketika ketahanan tubuh inang tidak adekuat dapat menimbulkan infeksi lokal yang secara klinik dapat mencapai aliran daran lalu menimbulkan sepsis. ${ }^{4-6}$

Manfaat propolis sebagai antibakteri telah banyak dilaporkan namun semuanya tergantung komposisi kimia propolis yang sesuai iklim dan lingkungan. Propolis Jerman menunjukkan tingginya efek antibakteri terhadap Staphylococcus aureus dan Escherichia coli sedangkan propolis Austria memiliki kehandalan melawan Candida albican. Propolis Prancis sangat efektif terhadap semua kuman patogen tetapi lebih rendah dibanding propolis Jerman dan Austria. $^{7}$

Berdasarkan latar belakang di atas, perlu diteliti efek antibakteri propolis terhadap Staphylococcus aureus dan Escherichia coli secara invitro.

\section{METODE}

Jenis penelitian ini adalah eksperimental dengan tiga kali pengulangan untuk mengetahui perbedaan daya hambat bakteri propolis cair yang ada di pasaran terhadap Escherichia coli dan Staphylococcus aureus secara In vitro. Variabel penelitian adalah jenis propolis dan jenis bakteri. Propolis yang digunakan dibagi Propolis cair 1 (diklaim berasal dari Malaysia) dan Propolis cair 2 (diklaim berasal dari Selandia baru) dengan konsentrasi $100 \%$.

Penilaian daya hambat propolis terhadap Escherichia coli dan Staphylococcus aureus dilakukan dengan mengukur diameter daerah bebas 
kuman dengan menggunakan mistar. Perbedaan diameter bebas kuman dari Propolis 1 dan 2 membuktikan adanya perbedaan daya hambat dari kedua merk propolis yang ada di pasaran.

Pertumbuhan kuman Escherichia coli dan Staphylococcus aureus diambil dari biakan murni, kemudian biakan diperbanyak pada cawan petri yang berisi medium agar Mueller Hinton. 7,8

Semua alat yang terbuat dari kaca terlebih dahulu dicuci dan dikeringkan, kemudian dibungkus dengan kertas perkamen.Sterilisasi dilakukan dengan otoklaf pada suhu $121^{\circ} \mathrm{C}$ dengan tekanan 15 pon selama 15 menit. Sterilisasi jarum ose dan pinset dilakukan dengan pemijaran. ${ }^{7,8}$

Cakram dibuat dengan merekatkan tiga lapis kertas saring yang didapatkan dengan bantuan alat pelobang kertas berukuran $4 \mathrm{~mm}$. Kemudian disusun dalam cawan petri dan disterilkan dalam oktoklaf selama 15 menit.Suspensi kuman dibuat dari biakan murni yang telah dipermuda selama 24 jam pada medium Mueller Hinton. ${ }^{7,8}$

Sebanyak 0,5 $\mathrm{ml}$ suspensi kuman diambil dan diinokulasikan pada permukaan Agar Diagnostic Sensitivity Test (DST). Kemudian diratakan dengan lidi kapas steril, selanjutnya dikeringkan pada suhu kamar. Kemudian masing-masingnya diletakkan secara aseptis cakram-cakram yang sudah dicelupkan ke dalam propolis dengan konsentrasi $100 \%$ dan diinokulasikan pada suhu $37^{\circ} \mathrm{C}$ selama 24 jam. Efek antibakteri propolis dapat ditentukan dengan mengukur daerah bening (halo) di sekitar cakram dengan menggunakan mistar. 7,8

Data yang diperoleh dari penelitian disajikan dalam bentuk tabel dan selanjutnya diolah secara statistik dengan menggunakan uji one way ANOVA dengan tingkat kepercayaan 99\%. Jika didapatkan hasil yang bermakna maka dilanjutkan dengan Post Hoc Test. ${ }^{9,10}$

HASIL

Propolis yang digunakan adalah propolis cair yang beredar di pasaran. Tabel 1 memperlihatkan bahwa pengujian Propolis 1 (A) dan Propolis 2 (B) tidak memiliki daya hambat bakteri terhadap Escherichia coli.
Tabel 1. Hasil daya hambat propolis 1 dan propolis 2 terhadap kuman Escherichia coli

\begin{tabular}{|c|c|c|c|c|c|}
\hline \multirow[t]{2}{*}{ No } & \multirow[t]{2}{*}{ Propolis } & \multicolumn{2}{|c|}{ Pengulangan } & \multicolumn{2}{|c|}{$\begin{array}{c}\text { Rerata } \\
\text { (cm) }\end{array}$} \\
\hline & & I & II & \multicolumn{2}{|l|}{ III } \\
\hline 1. & $A_{1}$ & - & - & - & - \\
\hline 2. & $\mathrm{~B}_{1}$ & - & - & - & - \\
\hline 3. & $A_{2}$ & - & - & - & - \\
\hline 4. & $\mathrm{~B}_{2}$ & - & - & - & - \\
\hline 5. & $\mathrm{~A}_{3}$ & - & - & - & - \\
\hline 6. & B3 & - & - & - & - \\
\hline \multicolumn{6}{|c|}{ Keterangan: A1 = Propolis 1 perlakuan I } \\
\hline \multicolumn{6}{|c|}{ B1 = Propolis 2 perlakuan 1} \\
\hline \multicolumn{6}{|c|}{ A2 = Propolis 1 perlakuan 2} \\
\hline \multicolumn{6}{|c|}{ B2 = Propolis 2 perlakuan 2} \\
\hline \multicolumn{6}{|c|}{ A3 = Propolis 1 perlakuan 3} \\
\hline \multicolumn{6}{|c|}{ B3 = Propolis 2 perlakuan 3} \\
\hline
\end{tabular}

Tabel 2 memperlihatkan adanya perbedaan daya hambat pertumbuhan bakteri dari Propolis 1 (A) dan Propolis 2 (B). Propolis 2 (B) memiliki rerata daya hambat bakteri lebih baik dibanding Propolis 1 (A). Hasil penelitian diolah dengan uji one way ANOVA yang dilanjutkan dengan metode RAL Dua Faktor dengan hasil daya hambat bakteri kedua propolis terhadap Staphylococcus aureus berbeda secara signifikan $(<0,05)$

Tabel 2. Hasil daya hambat propolis 1 dan propolis 2 terhadap kuman Staphylococcus aureus

\begin{tabular}{|c|c|c|c|c|c|}
\hline \multirow[t]{2}{*}{ No } & \multirow{2}{*}{$\begin{array}{c}\text { Jenis } \\
\text { Propolis }\end{array}$} & \multicolumn{3}{|c|}{ Pengulangan } & \multirow{2}{*}{$\begin{array}{c}\text { Rerata } \\
\text { (cm) }\end{array}$} \\
\hline & & $T$ & II & III & \\
\hline 1. & $A_{1}$ & 1,2 & 1 & 1 & 1,1 \\
\hline 2. & $\mathrm{~B}_{1}$ & 1,5 & 1,1 & 1,1 & 1,2 \\
\hline 3. & $A_{2}$ & 1 & 1 & 1 & 1 \\
\hline 4. & $\mathrm{~B}_{2}$ & 1,3 & 1,1 & 1,1 & 1,2 \\
\hline 5. & $\mathrm{~A}_{3}$ & 1 & 1 & 1 & 1 \\
\hline 6. & $\mathrm{~B}_{3}$ & 1,2 & 1,2 & 1,2 & 1,2 \\
\hline \multicolumn{6}{|c|}{ Keterangan: A1 = Propolis 1 perlakuan I } \\
\hline \multicolumn{6}{|c|}{ B1 = Propolis 2 perlakuan 1} \\
\hline \multicolumn{6}{|c|}{ A2 = Propolis 1 perlakuan 2} \\
\hline \multicolumn{6}{|c|}{$\mathrm{B} 2$ = Propolis 2 perlakuan 2} \\
\hline \multicolumn{6}{|c|}{ A3 = Propolis 1 perlakuan 3} \\
\hline \multicolumn{6}{|c|}{ B3 = Propolis 2 perlakuan 3} \\
\hline
\end{tabular}




\section{PEMBAHASAN}

Propolis 1 dan Propolis 2 yang beredar di pasaran merupakan dua propolis yang berasal dari daerah berbeda. Propolis 1 berasal dari negara Malaysia dan Propolis 2 berasal dari negara Selandia Baru. Getah tanaman dan air liur lebah madu (Apis melifera) yang merupakan bahan baku utama propolis juga berbeda, hal ini bisa menjadi salah satu faktor yang dapat membedakan daya hambat bakteri dua propolis yang berasal dari daerah berbeda.

Berdasarkan hasil penelitian yang dilakukan, Propolis 1 dan Propolis 2 tidak memiliki daya hambat bakteri terhadap Escherichia coli, sedangkan kedua propolis memiliki daya hambat bakteri terhadap Staphylococcus aureus. Hasil penelitian membuktikan bahwa Propolis 2 memiliki daya hambat bakteri yang lebih baik terhadap Staphylococcus aureus daripada propolis 1. Diameter daerah bebas kuman terbesar terdapat pada propolis $B$ (propolis 2) yaitu $1,5 \mathrm{~cm}$.

Pada Tabel 1, kedua jenis propolis tidak memperlihatkan daerah bebas kuman ketika diuji dengan Escherichia coli. Tetapi kedua propolis memiliki daya hambat bakteri yang berbeda terhadap Staphylococcus aureus. Diameter daerah bebas kuman terbesar terdapat pada Propolis 2 yaitu 1,5 $\mathrm{cm}$.Hal ini dipengaruhi jenis getah tanaman, sifat lebah, iklim dari dua wilayah berbeda menyebabkan perbedaan komposisi kimia pada kedua propolis dan juga disebabkan perbedaan sifat dari kedua bakteri.

Hasil uji statistik menunjukkan bahwa daya hambat bakteri kedua propolis terhadap Staphylococcus aureus berbeda secara signifikan. $\mathrm{Hal}$ ini bisa disebabkan jenis getah tanaman dan sifat lebah serta iklim dari dua wilayah berbeda menyebabkan perbedaan komposisi kimia pada kedua propolis sehingga daya hambat bakteri nya terhadap Staphylococcus aureus juga menunjukkan perbedaan yang signifikan.

\section{KESIMPULAN}

Propolis 1 dan Propolis 2 tidak memiliki efek antibakteri terhadap Escherichia coli sedangkan kedua propolis ini memperlihatkan daerah bebas kuman yang berbeda terhadap Staphylococcus aureus. Propolis 2 memiliki efek antibakteri yang lebih baik jika dibandingkan dengan Propolis 1 terhadap Staphylococcus aureus.

\section{UCAPAN TERIMAKASIH}

Terimakasih kepada seluruh staf Laboratorium Mikrobiologi Fakultas Kedokteran Universitas Andalas dan semua pihak yang sudah membantu dalam penyelesaian tugas akhir ini.

\section{DAFTAR PUSTAKA}

1. Grange JM. Department of Microbakterial, National Heart \& Lung Institute, London. 1990 (diunduh 5 November 2012). Tersedia dari: URL: HYPERLINK http:/www.ncbi.nlm.nih.gov/pubmed/2182860

2. Hasan AEZ. Potensi propolis lebah madu trigona spp. sebagai bahan antibakteri. Bogor: Seminar Nasional HKI:2006;4-7.

3. Sabir A. Aktivitas antibakteri Flavonoid propolis Trigona sp terhadap bakteri Streptococcus mutans(in vitro). Makassar: Fakultas Kedokteran Gigi Universitas Hasanuddin; 2005.

4. Jawetz, Melnick, Adelberg's. Mikrobiologi Kedokteran. Edisi ke- 23. Jakarta: EGC; 2004.

5. Josodiwondo S. Kokus Negatif Gram. Dalam Mikrobiologi Kedokteran. Jakarta: Binarupa Aksara; 1998. hlm.163-5

6. Warsa, Usman C. Kokus positif gram. Dalam Mikrobiologi Kedokteran. Jakarta: Binarupa Aksara; 1994. hlm.103-10.

7. Handayani R. Perbandingan daya hambat madu murni dengan madu kemasan terhadap Shigella dysentriae secara invitro (skripsi); 2007.

8. Notoatmodjo S. Metodologi penelitian kesehatan. Jakarta: PT Rineka Cipta; 2010.

9. Singgih. Dalam: Ria Handayani. Perbandingan Daya Hambat Madu Murni dengan Madu Kemasan terhadap Shigella Dysentriae secara In Vitro (skripsi);2007: 24.

10. Sopiyadin. Dalam: Ria Handayani. Perbandingan Daya Hambat Madu Murni dengan Madu Kemasan terhadap Shigella Dysentriae secara In Vitro (skripsi);2007: 24. 